\title{
Ketersediaan Data dalam Mendukung Smart City Readiness di Kota Surakarta
}

\author{
Data Availability in Supporting Smart City Readiness in Surakarta City \\ Miraeki Herawati ${ }^{1 *}$ \& Achmad Djunaedi ${ }^{1}$ \\ ${ }^{1}$ Magister Perencanaan Wilayah dan Kota, Fakultas Teknik, Universitas Gadjah Mada, \\ Jalan Grafika Nomor 2 Kampus Universitas Gadjah Mada, Yogyakarta 55281, Indonesia; \\ *Penulis korespondensi.e-mail: miraeki.herawati@mail.ugm.ac.id \\ (Diterima: 14 Mei 2019; Disetujui: 8 Januari 2020)
}

\begin{abstract}
The smart city concept is one of the developing concepts in overcoming various urban problems. The concept must be supported by mature implementation guidelines. The preparation of smart city guidelines is based on the readiness of each region. The readiness measurement is carried out with smart city readiness measurements that have been developed by several experts. This study will use compilation of several smart city readiness measurement models to measure smart city readiness in Surakarta City, in order to understand data required and available in Surakarta City Government, data required and available outside Surakarta City Government, and data required but not yet provided by both the City Government and other agencies. The method used in this study is case study with a qualitative approach. Measurement results show that the availability of data and the quality of available data in Surakarta City is quite good. This shows that Surakarta City is ready to develop the smart city concept to overcome various city problems faced.
\end{abstract}

Keywords: data availability, digital data, smart city, smart city readiness, Surakarta City

\section{ABSTRAK}

Konsep smart city merupakan salah satu konsep yang sedang berkembang dalam mengatasi berbagai permasalahan perkotaan. Konsep tersebut harus didukung dengan pedoman pelaksanaan yang matang. Penyusunan pedoman smart city didasarkan dari kesiapan masing-masing daerah. Pengukuran kesiapan tersebut dilakukan dengan pengukuran smart city readiness yang telah dikembangkan oleh beberapa ahli. Penelitian ini menggunakan kompilasi dari beberapa model pengukuran smart city readiness untuk mengukur kesiapan smart city di Kota Surakarta, sehingga dapat diketahui data apa saja yang dibutuhkan dan sudah tersedia di Pemerintah Kota Surakarta, data yang dibutuhkan dan tersedia di luar Pemerintah Kota Surakarta, serta data yang dibutuhkan namun belum disediakan baik oleh Pemerintah Kota maupun oleh instansi lain. Metode yang digunakan dalam penelitian ini adalah studi kasus dengan pendekatan kualitatif. Hasil pengukuran menunjukkan bahwa ketersediaan data dan kualitas data yang tersedia di Kota Surakarta sudah cukup baik. Hal ini menunjukkan bahwa Kota Surakarta telah siap untuk mengembangkan konsep smart city untuk mengatasi berbagai permasalahan kota yang dihadapi.

Kata kunci: data digital perkotaan, ketersediaan data, Kota Surakarta, smart city, smart city readiness 


\section{PENDAHULUAN}

Smart City merupakan salah satu solusi untuk menghadapi masalah perkotaan yang saat ini banyak diterapkan oleh sebagian besar kota di seluruh dunia. Permasalahan perkotaan ini salah satunya mulai muncul dari banyaknya penduduk yang datang ke kota dan menimbulkan banyak dampak negatif seperti degradasi lingkungan, kesenjangan ekonomi, dan penurunan nilai sosial budaya. Diperlukan upaya untuk dapat mengendalikan dan mengarahkan perkembangan perkotaan menjadi lebih berkelanjutan dengan merumuskan suatu konsep yang dapat mengatasi berbagai permasalahan perkotaan.

Menurut Bakici et al. (2013), pada dasarnya tidak ada penjelasan smart city yang pasti, tetapi kota dikatakan cerdas dengan menggunakan teknologi informasi dan komunikasi dengan tujuan untuk meningkatkan kualitas hidup masyarakat selama menyediakan pembangunan berkelanjutan. Sedangkan menurut Caragliu et al. (2011), kota akan menjadi pintar apabila investasi pada sumber daya manusia dan modal sosial serta infrastruktur sistem komunikasi tradisional dan modern dapat meningkatkan pertumbuhan ekonomi yang berkelanjutan dan kehidupan yang berkualitas dengan pengelolaan sumber daya alam yang bijaksana melalui tata pemerintahan yang partisipatif.

Jadi, dapat disimpulkan bahwa konsep smart city ini merupakan konsep perencanaan kota dengan memanfaatkan perkembangan teknologi yang akan membuat hidup lebih mudah dan sehat dengan tingkat efisiensi dan efektivitas yang tinggi. Hal ini mampu memecahkan masalah fisik, sosial, dan ekonomi dengan teknologi serta sumber daya yang ada pada kota tersebut. Konsep ini bertujuan untuk memberikan kemudahan bagi masyarakat (Insani, 2017).

Cohen (2010) menyebutkan bahwa smart city diidentifikasikan pada 6 (enam) dimensi utama yaitu smart government, smart economy, smart society, smart mobility, smart environment dan quality of live.
Untuk menerapkan konsep smart city diperlukan sebuah strategi untuk mengatur perencanaan dan pelaksanaan agar konsep tersebut dapat berjalan dengan baik. Strategi yang disusun oleh masing-masing kota berbeda antara satu dengan yang lainnya tergantung dari kesiapan pemerintah kota dalam melaksanakan konsep smart city atau yang lebih dikenal dengan sebutan smart city readiness.

Menurut Utomo \& Hariadi (2016), strategi dalam pembangunan smart city ditempuh menyesuaikan dengan segala potensi yang dimiliki dan keadaan serta kondisi di daerah masing-masing. Dasar dari konsep smart city menurut Harrison et al. (2010) pada umumnya bercirikan tiga hal yaitu instrumented (dapat diakses dengan mudah), interconnected (dapat terhubung satu dengan lainnya), dan intelligent (sistem yang dapat mengorganisir sampai proses akhir).

Penyusunan strategi smart city ini juga tidak terlepas dari berbagai data yang ada di masing-masing kota sehingga dapat disusun berbagai rumusan yang sesuai dengan karakteristik kota tersebut. Pada prinsipnya pengukuran yang dilakukan untuk mengetahui kesiapan daerah dalam menerapkan konsep smart city di daerahnya. Dari hasil pengukuran tersebut akan diketahui kekuatan, kelemahan, tantangan dan peluang sehingga dapat dijadikan acuan dalam perumusan strategi yang akan dilakukan. Kendati demikian kesuksesan dari smart city ini dapat dilihat dari beberapa faktor yaitu visi, kepemimpinan, kondisi bisnis, inovasi, keterkaitan masyarakat, pemerintahan, pembiayaan, kerjasama, arsitektur infrastruktur, adaptasi teknologi, dan penggunaan data dalam meningkatkan layanan dan akses masyarakat (Azim \& Aghajani, 2014).

Pengukuran smart city readiness telah dilakukan oleh beberapa ahli yang menghasilkan model pengukuran yang berbeda. Model ini harus disesuaikan dengan kondisi daerah masing-masing sehingga pengukuran dapat dilakukan dengan benar. Pengukuran smart city readiness oleh Molla \& Licker (2005) dan Dada (2007) menggunakan metode e-readiness dengan menggunakan 6 indikator 
yaitu awareness, government, komitmen, sumber daya manusia, teknologi dan adopsi.

Penelitian ini akan membahas mengenai (1) data yang dibutuhkan dan sudah tersedia beserta kualitas datanya di Pemerintah Kota, (2) data yang dibutuhkan dan sudah tersedia di luar Pemerintah Kota tapi belum dikumpulkan oleh Pemerintah Kota, dan (3) data yang dibutuhkan tapi belum tersedia dimanapun sehingga perlu dilakukan upaya pengumpulan data.

\section{METODOLOGI}

Pendekatan penelitian yang diambil dalam penelitian ini adalah pendekatan kualitatif dengan metode studi kasus. Lokasi penelitian di Kota Surakarta dengan alasan karena Kota Surakarta terpilih menjadi salah satu kota dalam Gerakan Menuju 100 Smart City yang diinisiasi oleh Kementerian Komunikasi dan Informatika.

Data yang digunakan dalam penelitian ini adalah data primer dan sekunder. Data primer diperoleh dari observasi langsung ke lapangan dan wawancara dengan beberapa narasumber dari perangkat daerah terkait untuk mengetahui ketersediaan dan kualitas data penelitian. Fokus wawancara pada ketersediaan dan kualitas dari data yang sedang diteliti. Wawancara dilakukan pada bulan Oktober sampai Desember 2018. Sedangkan data sekunder diperoleh dari dokumen, laporan, artikel maupun website dari perangkat daerah terkait.

Pengukuran yang dilakukan didasarkan pada beberapa pedoman model pengukuran dari Smart City Readiness Guide oleh Smart City Council, Smart City Readiness (Smart Cities Summit), Smart City Readiness Model Based on Technology Organization Environment (TOE) Framework and its effect on adoption decision, Citiasia Smart City Readiness Model dan model pengukuran terakhir dari Smart City Readiness Singapore.

a. Smart City Readiness Guide merupakan hasil dari kolaborasi banyak ahli smart city dari seluruh dunia yang tergabung dalam
Smart Cities Council. Pedoman ini mulai dapat digunakan sejak tahun 2013 yang membantu setiap kota untuk dapat menjadi smart city yang disesuaikan dengan kapasitas dan kemampuannya.

b. Smart City Readiness (Smart Cities Summit) merupakan pedoman yang dihasilkan pada smart cities summit di tahun 2017.

c. Smart City Readiness Model Based on Technology Organization Environment (TOE) Framework and its effect on adoption decision merupakan konsep smart city readiness dari hasil penelitian Dewi et al. (2018) yang mencoba untuk mendesain berdasarkan kerangka teknologi, organisasi, dan lingkungan. Penelitian ini dihasilkan pada tahun 2018.

d. Citiasia Smart City Readiness Model merupakan pedoman yang digagas oleh Citiasia Center for Smart Nation (CCSN) yang menggabungkan beberapa model sehingga menjadi model yang lebih canggih dan lebih mudah untuk digunakan.

e. Smart City Readiness Singapore merupakan model pengembangan smart city yang dilakukan di Singapura sejak tahun 2014. Model ini tidak hanya berfokus pada teknologi namun juga meningkatkan berbagai transformasi pada skala nasional.

Dari beberapa model pengukuran di atas, dapat diketahui bahwa pengukuran yang dilakukan berbeda-beda. Namun ternyata ada beberapa persamaan data atau variabel pengukuran. Beberapa variabel tersebut akan dikelompokkan sesuai dengan fungsinya masing-masing sehingga akan terlihat lebih jelas mengenai variabel pengukuran yang lebih banyak dilakukan. Variabel tersebutlah yang akan digunakan dalam penelitian ini.

\section{HASIL DAN PEMBAHASAN}

Dari beberapa model smart city readiness di atas, maka karakteristik pengukuran dari masing-masing model dapat dirangkum seperti tabel di bawah ini: 
Journal of Regional and Rural Development Planning (Jurnal Perencanaan Pembangunan Wilayah dan Perdesaan) Februari 2020, 4 (1): 63-73

Tabel 1. Rangkuman smart city readiness

\begin{tabular}{|c|c|c|c|c|}
\hline $\begin{array}{c}\text { Smart city Readiness } \\
\text { Guide }\end{array}$ & $\begin{array}{c}\text { Smart city } \\
\text { Readiness (Smart } \\
\text { Cities Summit) }\end{array}$ & $\begin{array}{c}\text { Smart city Readiness } \\
\text { Model Based on TOE } \\
\text { Framework }\end{array}$ & $\begin{array}{l}\text { Citiasia Smart } \\
\quad \text { Nation }\end{array}$ & Singapore Readiness \\
\hline - Enabler & $\begin{array}{l}\text { - Kerjasama } \\
\text { pemerintah } \\
\text { swasta }\end{array}$ & $\begin{array}{r}\text { - Kesiapan } \\
\text { teknologi }\end{array}$ & - Potensi alam & $\begin{array}{l}\text { - Test bedding dan } \\
\text { kolaborasi } \\
\text { penelitian }\end{array}$ \\
\hline $\begin{array}{l}\text { - Peralatan dan } \\
\text { kontrol }\end{array}$ & $\begin{array}{l}\text { - Keterbukaan } \\
\text { data dan } \\
\text { kolaborasi } \\
\text { pihak ketiga }\end{array}$ & $\begin{array}{l}\text { - Peralatan dan } \\
\text { kontrol }\end{array}$ & - Struktur & - Keterbukaan data \\
\hline - Konektivitas & $\begin{array}{l}\text { - Sumber } \\
\text { informasi bagi } \\
\text { layanan } \\
\text { publik }\end{array}$ & - Konektivitas & $\begin{array}{l}\text { - Pembangunan } \\
\text { SDM }\end{array}$ & $\begin{array}{l}\text { - Investasi dalam } \\
\text { litbang }\end{array}$ \\
\hline - Interoperabilitas & $\begin{array}{l}\text { - Konektivitas } \\
\text { internet }\end{array}$ & - Interoperabilitas & $\begin{array}{l}\text { - Penyiapan } \\
\text { anggaran }\end{array}$ & $\begin{array}{l}\text { - Laboratorium uji } \\
\text { coba solusi } \\
\text { teknologi }\end{array}$ \\
\hline $\begin{array}{l}\text { - Privasi dan } \\
\text { keamanan }\end{array}$ & - Smart Kiosks & $\begin{array}{l}\text { - Manajemen data } \\
\text { dan analitik }\end{array}$ & - Infrastruktur & $\begin{array}{l}\text { - Menumbuhkan } \\
\text { industri }\end{array}$ \\
\hline - Manajemen data & $\begin{array}{l}\text { - Layanan } \\
\text { transportasi } \\
\text { cerdas }\end{array}$ & $\begin{array}{l}\text { - Layanan dan } \\
\text { privasi }\end{array}$ & $\begin{array}{l}\text { - Pembangunan } \\
\text { infrastruktur } \\
\text { fisik dan digital }\end{array}$ & - Keamanan siber \\
\hline $\begin{array}{l}\text { - Sumber daya } \\
\text { komputer }\end{array}$ & $\begin{array}{l}\text { - Keamanan } \\
\text { layanan } \\
\text { publik }\end{array}$ & $\begin{array}{l}\text { - Kesiapan } \\
\text { organisasi }\end{array}$ & - Suprastruktur & $\begin{array}{l}\text { - Membangun } \\
\text { kemampuan } \\
\text { komputasi }\end{array}$ \\
\hline - Analitik & $\begin{array}{l}\text { - Solusi yang } \\
\text { berkelanjutan }\end{array}$ & $\begin{array}{l}\text { - Tersedianya } \\
\text { tenaga ahli }\end{array}$ & - Kebijakan & \\
\hline- & $\begin{array}{l}\text { - Sistem voting } \\
\text { digital }\end{array}$ & $\begin{array}{l}\text { - Dukungan dari } \\
\text { top management }\end{array}$ & - Kelembagaan & \\
\hline - Tanggungjawab & $\begin{array}{l}\text { - Kesiapan } \\
\text { untuk } \\
\text { kendaraan } \\
\text { otomatis }\end{array}$ & $\begin{array}{l}\text { - Strategi } \\
\text { pendanaan }\end{array}$ & $\begin{array}{l}\text { - Tata laksana } \\
\text { pelaksanaan } \\
\text { smart city }\end{array}$ & \\
\hline - Bangunan & & $\begin{array}{l}\text { - Kesiapan } \\
\text { lingkungan }\end{array}$ & - Mediator & \\
\hline - Energi & & $\begin{array}{l}\text { - Keberhasilan } \\
\text { warga dalam } \\
\text { penggunaan } \\
\text { komputer dan } \\
\text { internet }\end{array}$ & & \\
\hline - Telekomunikasi & & $\begin{array}{l}\text { - Keterlibatan } \\
\text { warga }\end{array}$ & & \\
\hline $\begin{array}{l}\text { - Pengelolaan } \\
\text { limbah } \\
\text { - Keuangan } \\
\text { - Transportasi } \\
\text { - Pelayanan publik } \\
\text { - Air } \\
\text { - Keamanan publik }\end{array}$ & & $\begin{array}{l}\text { - Kemitraan dan } \\
\text { kolaborasi }\end{array}$ & & \\
\hline
\end{tabular}

Dari rangkuman model di atas, dapat dilihat bahwa terdapat persamaan indikator pengukuran dari beberapa model smart city readiness yang telah ada. Indikator tersebut akan dikelompokkan sesuai dengan kesamaan fungsinya yang mengacu pada smart city readiness guide oleh Smart Cities Council. Hasil dari pengelompokan tersebut dapat dilihat pada Tabel 2. 
Tabel 2. Kompilasi smart city readiness

\begin{tabular}{lll}
\hline Teknologi & Kelembagaan & Lingkungan \\
\hline Peralatan dan Kontrol & Strategi Pendanaan & Kemitraan dan Kolaborasi \\
Konektivitas & Transportasi & Energi \\
Interoperabilitas & Pembayaran dan Keuangan & Manajemen \\
Keamanan dan privasi & Pelayanan Publik & Limbah \\
Manajemen Data & Keamanan Publik & Air \\
\hline
\end{tabular}

Dari Tabel 2 dapat diketahui bahwa ada 3 kelompok besar pengukuran yaitu teknologi, kelembagaan dan lingkungan. Kelompok teknologi merupakan kelompok data yang berhubungan dengan struktur, kualitas dan karakteristik teknologi yang dapat mempengaruhi proses adopsi suatu inovasi. Kelompok kelembagaan merupakan kelompok data yang berhubungan dengan beberapa atribut kelembagaan. Sedangkan kelompok lingkungan merupakan kelompok data yang berhubungan dengan kondisi lingkungan dan pihak eksternal lainnya. Masing-masing dari kelompok tersebut memiliki komponen pengukuran yang berbeda, dan setiap komponen juga memiliki indikator pengukuran sendiri.

Indikator pengukuran yang akan digunakan dalam penelitian ini menggunakan indikator dalam smart city readiness guide oleh Smart Cities Council karena model pengukuran yang lain tidak mencantumkan indikator untuk pengukurannya. Penjelasan dari indikator yang akan diteliti terlihat dalam Tabel 3.

Tabel 3. Data indikator yang diteliti

\begin{tabular}{|c|c|}
\hline \multicolumn{2}{|c|}{$\begin{array}{l}\text { No. V arlabel/1ndikator } \\
\text { Teknologi }\end{array}$} \\
\hline 1 & \begin{tabular}{ll}
\multicolumn{2}{l}{ Peralatan dan kontrol } \\
- & Sensor kualitas udara \\
- & Sensor jalan \\
- & CCTV \\
- & Meteran listrik dan air
\end{tabular} \\
\hline 2 & $\begin{array}{l}\text { Konektivitas } \\
\text { - } \quad \text { Jaringan wifi } \\
\text { - } \quad \text { Jaringan Mesh RF } \\
\text { - } \quad \text { Jaringan seluler }\end{array}$ \\
\hline 3 & $\begin{array}{l}\text { Interoperabilitas } \\
-\quad \text { Standar terbuka }\end{array}$ \\
\hline 4 & $\begin{array}{l}\text { Keamanan dan privasi } \\
-\quad \text { Privasi } \\
\text { - } \quad \text { Sistem keamanan siber }\end{array}$ \\
\hline 5 & $\begin{array}{l}\text { Manajemen data } \\
\text { - } \quad \text { Pengelolaan data } \\
\text { - } \quad \text { Transparansi } \\
\text { - } \quad \text { Akses data }\end{array}$ \\
\hline
\end{tabular}

Tabel 3. Lanjutan

\begin{tabular}{|c|c|}
\hline \multirow{2}{*}{\multicolumn{2}{|c|}{$\begin{array}{l}\text { No. Variabel/Indikator } \\
\text { Organisasi }\end{array}$}} \\
\hline & \\
\hline 6 & $\begin{array}{l}\text { Strategi pendanaan } \\
-\quad \text { Sumber pendanaan } \\
-\quad \text { Alternatif sumber dana lain }\end{array}$ \\
\hline 7 & $\begin{array}{ll}\text { Transportasi } \\
\text { - } & \text { Transportasi umum } \\
\text { - } & \text { Mobil } \\
- & \text { Kendaraan roda dua } \\
\text { - } & \text { Jalur sepeda } \\
\text { - } & \text { Fasilitas transportasi }\end{array}$ \\
\hline 8 & 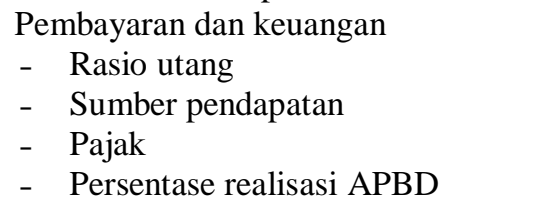 \\
\hline 9 & $\begin{array}{ll}\text { Pelayanan publik } \\
\text { - } & \text { Pendidikan } \\
\text { - } & \text { Kesehatan } \\
\text { - } & \text { Ruang Terbuka Hijau } \\
\text { - } & \text { Sarana rekreasi }\end{array}$ \\
\hline 10 & $\begin{array}{ll}\text { Keamanan publik } \\
\text { - } & \text { Petugas kepolisian } \\
\text { - } & \text { Kejahatan } \\
\text { - } & \text { Respon kepolisian } \\
\text { - } & \text { Petugas pemadam kebakaran } \\
\text { - } & \text { Respon petugas pemadam } \\
& \text { kebakaran }\end{array}$ \\
\hline \multicolumn{2}{|c|}{ Lingkungan } \\
\hline 11 & Kemitraan dan Kolaborasi \\
\hline 12 & $\begin{array}{ll}\text { Energi } \\
\text { - } & \text { Rasio ketersediaan daya listrik } \\
\text { - } & \text { Persentase RT yang menggunakan } \\
& \text { listrik } \\
\text { - } & \text { Total penggunaan listrik } \\
\text { - } & \text { Jumlah interupsi listrik } \\
\text { - } & \text { Panjang interupsi listrik }\end{array}$ \\
\hline 13 & $\begin{array}{l}\text { Manajemen Limbah } \\
\text { - } \quad \text { Masyarakat yang melakukan } \\
\text { pengelolaan limbah } \\
\text { - } \quad \text { Limbah dikelola pemerintah }\end{array}$ \\
\hline 14 & $\begin{array}{ll}\text { Air } \\
\text { - } & \text { Penduduk dengan layanan air } \\
& \text { bersih } \\
\text { - } & \text { Penduduk dengan akses ke sanitasi } \\
& \text { lebih baik } \\
\text { - } & \text { Konsumsi air domestik } \\
\text { - } & \text { Konsumsi air per kapita } \\
\text { - } & \text { Gangguan layanan air }\end{array}$ \\
\hline
\end{tabular}




\section{Data yang Dibutuhkan dan Telah Tersedia di Pemerintah Kota Surakarta}

\section{A. Ketersediaan Data Teknologi}

Dalam kesiapan teknologi ini akan dilihat mengenai seberapa jauh kesiapan Pemerintah dalam menyiapkan teknologi yang mendukung untuk pelaksanaan smart city. Investasi di bidang teknologi informasi dalam suatu organisasi sebagian besar bertujuan untuk dapat memberikan kontribusi yang positif terhadap kinerja individual anggota organisasi dan institusinya (Tampubolon, 2016). Dengan ketersediaan teknologi dan alat-alat penunjang teknologi tersebut berbagai macam data dan informasi yang berada di setiap sudut kota dapat dikumpulkan sehingga dapat dianalisis untuk mempermudah pelayanan (Mursalim, 2017).

Sesuai dengan penjabaran di Tabel 3, di Kota Surakarta telah memiliki beberapa data yang berkaitan dengan teknologi, yaitu data CCTV, meteran listrik dan air, jaringan wifi, standar terbuka, pengelolaan data, transparansi dan akses data.

\section{CCTV}

Data CCTV di Kota Surakarta dimiliki oleh Dinas Perhubungan dan Kepolisian dengan jumlah 130 CCTV yang tersebar di seluruh kota. CCTV ini digunakan untuk pengaturan dan penegakan pelanggaran lalu lintas. CCTV telah terpasang di semua ruas jalan utama dan beberapa sudut kota lainnya. Selain itu terdapat juga CCTV yang dipasang di gedung-gedung milik pemerintah dan juga swasta.

\section{Meteran Listrik dan Air}

Data meteran listrik di Kota Surakarta dimiliki oleh PLN sedangkan meteran air di PDAM. Data dari kedua meteran ini merupakan data penggunaan oleh konsumen setiap bulannya. Data tersebut dijadikan acuan dalam biaya yang dikenakan kepada konsumen sesuai dengan proporsi penggunaannya. Status penggunaan data dapat diketahui setiap hari.
3. Jaringan wifi

Pemerintah Kota Surakarta telah menyediakan layanan wifi gratis di beberapa ruang publik dan seluruh area perkantoran milik Pemerintah. Selain itu beberapa perusahaan swasta juga menyediakan akses wifi untuk menunjang pelayanannya. Dengan semakin tersebarnya jaringan wifi, diharapkan semakin mempermudah masyarakat dalam memperoleh informasi yang dibutuhkan.

4. Standar terbuka

Standar ini diinisiasi oleh Dinas Komunikasi, Infomatika, Statistik dan Persandian yang digunakan untuk standarisasi data dari seluruh perangkat daerah. Hal ini untuk mempermudah dalam melakukan integrasi data dan sharing data pembangunan.

5. Pengelolaan data

Pemerintah Kota Surakarta mengembangkan Sistem Satu Data Pemerintahan dan Pembangunan yang dikoordinir oleh Dinas Komunikasi, Infomatika, Statistik dan Persandian. Sistem satu data ini diwujudkan dalam bentuk portal layanan data berbasis web. Hal ini memberikan kemudahan pelayanan bagi masyarakat yang membutuhkan yaitu dengan hanya membuka satu website namun tersedia berbagai jenis data.

6. Transparansi

Pemerintah Kota Surakarta berusaha untuk memberikan semua informasi yang dibutuhkan oleh masyarakat terutama dalam pengelolaan anggaran keuangan. Hal ini ditunjukkan dengan adanya aplikasi APBD Online yang memberikan akses kepada masyarakat untuk mengetahui besaran APBD dari pendapatan hingga pengeluaran.

7. Akses data

Setiap data yang telah diupload dapat diakses oleh semua lapisan masyarakat. Kemudahan akses data ini juga ditunjang dengan fasilitas wifi yang telah disediakan. 


\section{B. Ketersediaan Data Kelembagaan}

Seluruh data kelembagaan yang menjadi kebutuhan data telah tersedia dan dimiliki oleh Pemerintah Kota Surakarta.

\section{Strategi Pendanaan}

Data pendanaan dari APBD Kota Surakarta tersedia dan dapat diakses melalui aplikasi maupun BPPKAD. Pendanaan juga tersedia dari sumber lainnya, yaitu dari APBD Provinsi, APBN maupun dari CSR perusahaan. Data ini sangat diperlukan sebagai acuan jumlah program smart city yang akan dilaksanakan. Semakin besar dana yang tersedia maka semakin cepat pula suatu kota dapat bertransformasi menjadi smart city.

2. Transportasi

Ketersediaan data transportasi (transportasi umum, mobil, kendaraan roda dua, jalur sepeda dan fasilitas transportasi) dapat diketahui melalui Dinas Perhubungan dan Kepolisian. Data ini untuk mengetahui persentase masyarakat dalam penggunaan transportasi. Dalam konsep smart city yang akan diterapkan, diharapkan masyarakat dapat beralih untuk menggunakan transportasi umum daripada transportasi pribadi. Hal ini juga harus didukung dengan penyediaan berbagai sarana dan fasilitas transportasi yang aman dan nyaman sehingga menarik minat masyarakat dalam menggunakannya. Data ini diupdate setiap bulannya sehingga dapat diketahui kondisi transportasi di Kota Surakarta.

\section{Pembayaran dan Keuangan}

Data mengenai rasio hutang tidak tersedia, namun data mengenai jumlah hutang dan jumlah aset tersedia di BPPKAD. Penghitungan dilakukan sendiri oleh pihakpihak yang membutuhkan. Sedangkan data lainnya yaitu data sumber pendapatan sendiri, pajak, dan persentase realisasi kinerja APBD tersedia dan dapat diakses melalui BPPKAD. Kondisi keuangan yang baik sangat diperlukan dalam pelaksanaan program-program smart city. Dengan berbagai peralatan dan fasilitas yang harus disediakan, maka pemerintah harus memiliki dana yang cukup untuk membiayainya.

4. Pelayanan Publik

Data mengenai fasilitas pendidikan tersedia di Dinas Pendidikan, fasilitas kesehatan di Dinas Kesehatan, ruang terbuka hijau di Dinas Lingkungan Hidup, dan sarana rekreasi di Dinas Pariwisata. Data-data tersebut tersedia dan dapat diakses baik melalui website maupun datang langsung ke perangkat daerah yang bersangkutan. Data yang diperoleh dari komponen ini dapat memberikan gambaran sejauhmana tanggung jawab pemerintah dalam memberikan layanan wajib kepada masyarakatnya. Data ini juga dilaporkan dalam Buku Surakarta Dalam Angka yang diterbitkan setiap tahunnya oleh BPS.

5. Keamanan Publik

Data mengenai petugas kepolisian, kejahatan, dan respon kepolisian tersedia dan dapat diakses melalui surat resmi. Sedangkan data petugas pemadam kebakaran dan respon petugas juga tersedia di Dinas Pemadam Kebakaran. Saat ini setiap kebakaran yang terjadi di Kota Surakarta akan diinformasikan melalui laman resmi Dinas Pemadam Kebakaran yang berisi mengenai informasi lokasi kebakaran, respon petugas, kerugian, dan lain-lain. Rasa aman merupakan hak dari setiap masyarakat yang hidup di kota tersebut. Semakin sedikit jumlah kejahatan yang terjadi menunjukkan semakin aman kota tersebut untuk ditinggali. Kecepatan respon petugas kepolisian dan petugas pemadam kebakaran dari setiap laporan yang diterima juga merupakan salah satu poin penting yang dapat meningkatkan rasa aman warga untuk hidup di kota tersebut.

Dari pembahasan di atas, maka dapat diketahui bahwa di Kota Surakarta telah tersedia berbagai data yang dibutuhkan sesuai dengan tabel kebutuhan data. Data-data yang tersedia tersebut dapat dirangkum seperti tabel di bawah ini: 
Tabel 4. Data yang dibutuhkan dan telah tersedia di Pemerintah Kota Surakarta

\begin{tabular}{|c|c|c|}
\hline Teknologi & Kelembagaan & Lingkungan \\
\hline $\begin{array}{l}\text { Peralatan dan kontrol } \\
\text { - } \quad \text { CCTV } \\
\text { - } \quad \text { Meteran Listrik dan } \\
\quad \text { Air }\end{array}$ & $\begin{array}{l}\text { Strategi Pendanaan } \\
\text { - } \quad \text { Sumber Pendanaan } \\
\text { - } \quad \text { Alternatif Sumber Dana Lain }\end{array}$ & Kemitraan dan kolaborasi \\
\hline $\begin{array}{l}\text { Konektivitas } \\
\text { - } \quad \text { Jaringan wifi }\end{array}$ & \begin{tabular}{ll}
\multicolumn{2}{l}{ Transportasi } \\
- & Transportasi Umum \\
- & Mobil \\
- & Kendaraan Roda Dua \\
- & Jalur Sepeda \\
- & Fasilitas Transportasi
\end{tabular} & $\begin{array}{ll}\text { Energi } \\
\text { - } & \text { Rasio Ketersediaan daya listrik } \\
\text { - } & \text { Persentase RT yang menggunakan listrik } \\
\text { - } & \text { Total Penggunaan Listrik } \\
\text { - } & \text { Jumlah Interupsi Listrik } \\
\text { - } & \text { Panjang Interupsi Listrik }\end{array}$ \\
\hline $\begin{array}{l}\text { Interoperabilitas } \\
-\quad \text { Standar terbuka }\end{array}$ & \begin{tabular}{ll}
\multicolumn{2}{l}{ Pembayaran dan Keuangan } \\
- & Rasio utang \\
- & Sumber Pendapatan \\
- & Pajak \\
- & Persentase Realisasi APBD
\end{tabular} & $\begin{array}{l}\text { Manajemen Limbah } \\
\text { - } \quad \text { Masyarakat yang melakukan } \\
\quad \text { Pengelolaan Limbah } \\
\text { - } \quad \text { Limbah dikelola Pemerintah }\end{array}$ \\
\hline $\begin{array}{l}\text { Manajemen Data } \\
\text { - } \quad \text { Pengelolaan data } \\
\text { - } \quad \text { Transparansi } \\
\text { - } \quad \text { Akses data }\end{array}$ & \begin{tabular}{ll}
\multicolumn{2}{l}{ Pelayanan Publik } \\
$-\quad$ & Pendidikan \\
- & Kesehatan \\
- & Ruang
\end{tabular} & 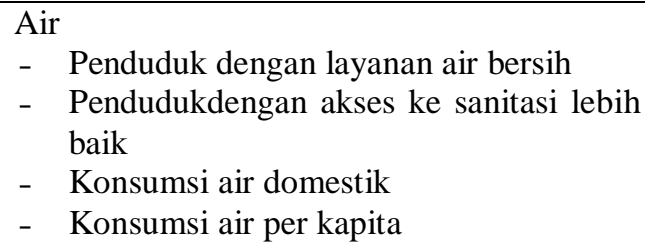 \\
\hline & $\begin{array}{ll}\text { Keamanan Publik } \\
\text { - } \quad \text { Petugas Kepolisian } \\
\text { - } \quad \text { Kejahatan } \\
\text { - } \quad \text { Respon Kepolisian } \\
\text { - } \quad \text { Petugas Pemadam Kebakaran } \\
\text { - } \quad \text { Respon petugas pemadam } \\
\quad \text { kebakaran }\end{array}$ & \\
\hline
\end{tabular}

\section{Ketersediaan Data Lingkungan}

1. Kemitraan dan Kolaborasi

Dalam pengembangan smart city diperlukan kerjasama dengan berbagai pihak terutama dari akademisi dan swasta. Dari pihak swasta, telah terjalin kerjasama dengan pihak perbankan (BNI, Mandiri, Bank Jateng) dan Telkom. Dengan keterlibatan aktif dari semua pihak, maka diharapkan konsep smart city ini dapat segera diterapkan.

2. Energi

Data energi seperti rasio ketersediaan daya listrik, persentase rumah tangga yang menggunakan listrik, total penggunaan energi listrik, jumlah dan panjang rata-rata interupsi listrik dapat diketahui dan tersedia di PLN. Informasi tersebut menjadi data yang dilaporkan oleh PLN setiap bulannya.

3. Manajemen Limbah

Data mengenai limbah, baik masyarakat yang melakukan pengelolaan limbah maupun limbah yang dikelola pemerintah tersedia di Dinas Lingkungan Hidup dan PDAM.

4. Air

Data mengenai air, seperti data penduduk kota dengan layanan pasokan air minum, penduduk dengan akses ke sanitasi lebih baik, konsumsi air domestik per kapita tersedia dan dapat diakses di PDAM. Data ini digunakan untuk mengetahui jumlah pemakaian air yang digunakan oleh masyarakat dalam suatu kota. Data tersebut diperbaharui setiap bulannya dan menjadi laporan resmi bulanan PDAM.

\section{Data Yang Belum Dikumpulkan Pemkot}

Data yang dimaksud di sini adalah data yang dibutuhkan sesuai dengan tabel kebutuhan data dan sudah tersedia di luar Pemerintah Kota Surakarta, namun data tersebut belum dikumpulkan oleh Pemkot. Data ini tersedia di lembaga atau perusahaan swasta sehingga 
membutuhkan kerjasama yang baik agar data tersebut dapat diberikan.

Data yang belum dikumpulkan ini adalah data jaringan seluler. Data mengenai penggunaan jaringan seluler ini terdapat di PT. Telkom. Data ini bersifat rahasia karena menyangkut keamanan penggunaan jaringan seluler sehingga untuk memperoleh data dimaksud dibutuhkan surat resmi dan proposal permintaan data.

\section{Data yang Dibutuhkan Namun Belum Tersedia}

\section{Data Teknologi}

Beberapa data teknologi yang belum tersedia di Pemerintah Kota Surakarta, yaitu:

a. Sensor kualitas udara

Sensor ini belum dimiliki oleh Pemerintah Kota Surakarta. Pengukuran kualitas udara hanya dilakukan di waktu tertentu saja dengan menggunakan peralatan yang telah tersedia. Selain itu dengan kualitas udara yang masih cukup bagus, penggunaan sensor ini masih belum terlalu dibutuhkan.

b. Sensor jalan

Sensor jalan ini juga belum dimiliki oleh Pemerintah Kota Surakarta. Pengaturan lalu lintas dilakukan melalui petugas yang berjaga dan dipantau melalui CCTV. Kemacetan hanya terjadi di jam-jam sibuk dan masih bisa diatasi dengan petugas lapangan yang ada dan bisa terurai dalam waktu yang tidak terlalu lama.

c. Jaringan Mesh RF

Data ini juga belum dimiliki oleh Pemerintah Kota Surakarta.

d. Kebijakan mengenai privasi

Kebijakan ini menjadi kewenangan pemerintah pusat sehingga tidak bisa dilakukan oleh pemerintah daerah. Kebijakan ini digunakan untuk melindungi setiap data pribadi warga negaranya yang telah terekam secara online.

e. Sistem Keamanan Siber

Data ini juga menjadi kewenangan pemerintah pusat. Keamanan siber harus dilakukan secara efektif dengan mengkoordinir semua unsur yang terkait .

\section{Data Lingkungan}

Data lingkungan yang tidak tersedia hanya data mengenai gangguan layanan air. Data ini seharusnya menjadi ranah PDAM. Namun sampai saat ini PDAM masih belum memiliki peralatan yang bisa mendeteksi adanya gangguan layanan air secara otomatis. Data mengenai gangguan yang terjadi hanya berdasar laporan dari warga. Perbaikan juga dilakukan setelah mendapatkan laporan dari warga perihal gangguan yang terjadi.

\section{KESIMPULAN DAN REKOMENDASI}

Dari hasil penelitian yang telah dilakukan di atas, maka ada 3 kelompok besar data yang harus dimiliki oleh Pemerintah Kota untuk dapat merencanakan smart city. Ketiga kelompok pengukuran tersebut adalah teknologi, kelembagaan, dan lingkungan. Masing-masing kelompok pengukuran tersebut diukur dengan menggunakan indikator yang ada dalam smart city readiness guide.

Dengan mengambil contoh di Kota Surakarta, maka dapat diketahui tingkat ketersediaan data yang mungkin dimiliki oleh Pemerintah Kota. Ketersediaan data di Kota Surakarta cukup baik untuk mendukung pelaksanaan smart city. Dengan hasil tersebut menunjukkan keseriusan pemerintah kota dalam menyediakan berbagai data yang dibutuhkan baik oleh pemerintah sendiri, masyarakat maupun pihak lainnya. Ketersediaan data dengan integrasi yang tinggi akan memudahkan pemerintah untuk menghasilkan informasi pembangunan yang lebih akurat.

Data dengan integrasi tinggi tersebut diperoleh dari adanya tata kelola data yang baik yang dilakukan oleh pemerintah. Namun, masih ada beberapa data yang belum tersedia di Pemerintah Kota Surakarta. Beberapa hal yang menyebabkan ketidaktersediaan data ini diantaranya:

1. Belum adanya peralatan yang mendukung untuk melakukan pengukuran sehingga kesulitan untuk memperoleh data yang dibutuhkan. Ketidaktersediaan peralatan ini bisa disebabkan karena harga peralatan 
yang mahal sehingga tidak cukup dibiayai dari anggaran pemerintah kota, atau bisa juga karena pemerintah merasa belum membutuhkan peralatan tersebut untuk dipasang di kota.

2. Beberapa data yang dibutuhkan masih belum dapat disediakan oleh perangkat daerah, namun data tersebut dapat disediakan oleh swasta. Oleh sebab itu, perlu adanya kajian untuk bekerjasama dengan pihak swasta dalam penyediaan data-data yang tidak dapat disediakan oleh pemerintah daerah. Data yang dimaksud misalnya data penggunaan telpon seluler yang dapat disediakan oleh pihak swasta / provider.

Untuk mengatasi berbagai permasalahan data yang ada di Kota Surakarta, berikut beberapa rekomendasi yang dapat dilakukan:

1. Bekerjasama dengan pihak swasta dalam penyediaan data-data spesifik yang dibutuhkan.

2. Perlu dilakukan penelitian mengenai datadata yang perlu disediakan untuk mengukur smart city maturity di Kota Surakarta khususnya. Data-data tersebut dapat digunakan untuk mengukur tingkat smart city maturity suatu kota.

\section{DAFTAR PUSTAKA}

Azim, A. Z. \& Aghajani, R. (2014). Designing Smart City. Indian Journal of Fundamental and Applied Life Sciences, 4 (S3), 146-153.

Bakici, T., Almirall, E., \& Wareham, J. (2013). A Smart City Initiative: the Case of Barcelona. Journal of the Knowledge Economy, 4 (2), 135-148.

Caragliu, C. D. (2011). Smart Cities in Europe. Journal of Urban Technology, 18 (2), 65-82.

Citiasia Center for Smart Nation. Smart Nation: Mastering Nation's Advancement from Smart Readiness to Smart City. Jakarta.
Cohen, Daniel, A., \& Zarowin, P. (2010). Accrual-Based and Real Earnings Management Activities Around Seasoned Equity Offerings. Journal of Accounting \& Economic, 50 (1), 2-19.

Dada, D. (2007). E-Readiness for Developing Countries: Moving the Focus from the Environment to the Users. The Electronic Journal of Information Systems in Developing Countries, 27 (6), 1-14.

Harrison, C., Eckman, B., Hamilton, R., \& Hartswick, P. (2010). Foundations for Smarter Cities. IBM Journal of Research and Development, 54 (4), 1-16.

Insani, P. A. (2017). Mewujudkan Kota Responsif melalui Smart City. PUBLISIA: Jurnal Ilmu Administrasi Publik, 2 (1), 25-31.

Dewi, M. A. A. D., Hidayanto, A. N., Purwandari B., Kosandi, M., \& Budi, N. F. A. (2018). Smart city Readiness Model Based on Technology Organization Environment (TOE) Framework and its effect on adoption decision. Paper presented at the Twenty-Second Pacific Asia Conference on Information Systems, Japan.

Molla, A. \& Licker, P. (2005). Perceived EReadiness Factors in E-Commerce Adoption : An Empirical Investigation in a Developing Country. International Journal of Electronic Commerce, (10) 1, 83-110.

Mursalim, S. W. (2017). Implementasi Kebijakan Smart City di Kota Bandung. Jurnal Ilmu Administrasi, 14 (1), 126138.

Smart City Council. (2013). Smart City Readiness Guide. Seattle.

Smart City Summit. (2016). The smart city checklist: 10 steps to smart city readiness. Chicago. 
Tampubolon, L. P. D. (2016). Pemeringkatan E-Government Indonesia (PEGI) dan Pemanfaatan Teknologi Informasi di DKI Jakarta. JSI: Jurnal Sistem Informasi, 8 (2), 1121-1132.

Utomo, C. E. W. \& Hariadi, M. (2016). Strategi Pembangunan Smart City dan Tantangannya bagi Masyarakat Kota. Jurnal Srategi dan Bisnis, 4 (2), 159176. 